\title{
The Europeanisation of Slovak Political Parties
}

\author{
Dušan Leška ${ }^{1}$
}

Katedra politológie a európskych štúdií, Fakulta sociálnych vied, UCM, Trnava

Europeizácia slovenských politických strán. Cielom štúdie je analyzovat' europeizáciu slovenských politických strán $v$ rôznych fázach prechodu a transformácie politického systému Slovenska pred a po vstupe do Európskej únie. Metodicky je práca odvodená od konceptu Ladrecha, ktorý rozdelil pät' oblastí výskumu na štúdium vplyvu europeizácie, na politické strany a ich politiku. Viditel'né sú zmeny $v$ politických programoch, organizačné zmeny, formula straníckej sút'aže, vzt’ahy medzi stranami a vládou, vzt'ahy mimo národného straníckeho systému (nový pohlad na nadnárodnej spolupráce medzi politickými stranami). Výskum preukázal, že europeizácia je viditel'ná vo všetkých fázach vývoja $s$ rôznou mierou intenzity a $v$ rôznych formách od podpísania dohody $o$ pridružení $s$ Európskou úniou. Významný bol jej vplyv už $v$ etape tranzície spoločnosti, kedy napomohla návrat Slovenska na cestu demokratického vývoja. $\checkmark$ dvoch etapách vývoja vytvorila europizácia samostatnú líniu štiepenia politických strán, ovplyvnila súperenie politických strán a tým aj model straníckeho systému. Jednoznačne sa premietla do politických programov všetkých strán, významnú úlohu zohralo začlenenie politických strán do Európskych politických strán, ich vzájomná spolupráca a koordinácia ich politiky. Dôležitými medzníkmi v dotváraní programových orientácií politických strán boli vol'by do Európskeho parlamentu.

Klúčové slová: Európska únia, europeizácia, slovenské politické strany, systém politických strán, tranzícia, transformácia

The Europeanisation of Slovak Political Parties. The aim of the study is to analyse the Europeanisation of Slovak political parties in the various stages of the transition and transformation of the political system of Slovakia before and after the entry into the European Union. Methodologically, the paper is based on the concept of Ladrech, who divided five areas of research to suit the study of the impact of the Europeanisation on political parties and their politics. Visible can be changes in political programmes, organisational changes, a formula of party competition, relations between parties and government, relations beyond the national party system (a new look at transnational cooperation between political parties). Our research proved that the Europeanisation has been visible at all stages of development, with varying degrees of intensity and in various forms since the signing of the association agreement with the European Union. Its effect was important already in the stage of the society transition when it helped the return of Slovakia on the path of democratic development. In the two stages of development, Europeanisation created an individual line of cleavage of political parties, affected the rivalry of political parties, and thus a party system model. Unambiguously, it was reflected in political programmes of all parties, and an

${ }^{1}$ Address: Doc. PhDr. Dušan Leška, PhD., Katedra politológie a európskych štúdií, Fakulta sociálnych vied, Univerzita Cyrila a Metoda v Trnave, Ul. Bučianska 4/A, dusan.leska@ucm.sk 
important role was played by the incorporation of political parties in the European political parties, by their cooperation and coordination of their policies. The election in the European Parliament was an important turning point in completion of programme orientations of political parties.

Key words: European Union, Europeanisation, Slovak political parties, system of political parties, transition, transformation

The research methodology of the Europeanisation of political parties in Slovakia

Europeanisation is a relatively wide concept primarily meaning an approach to the study of mutual interactions between the European Union and a domestic political system. The term Europeanisation is used in several contexts and refers to changes in individual member or candidate countries arising in the domestic economic and political system under the influence of the European Union. The term conditionality reflects this process from the point of view of the European Union; it describes the conditions required from the countries seeking to establish a closer relationship to the European Union, or aspiring to become its member. A specific form of a Europeanisation issue was demonstrated in the relation with the countries of Central and Eastern Europe that overthrew their totalitarian regimes and expressed their interest to join the European Union. The countries were required to complete the transition, the process of establishing the grounds of parliamentarian pluralist democracy and market economy in order to be accepted to the community of free democratic countries associated in the European Union. As state ownership of capital goods prevailed in these countries, privatization implying the establishment of market relations and market economy development was an import task to accomplish. The European Union provided these countries with help from the very first steps towards democracy. However, a problem arose when the readiness of these countries to join the European Union was discussed. Several authors study the question whether Europeanisation was active since these countries' transition, or whether it started implying after they joined the European Union. We believe that the conditionality of the European Union was, even if indirectly, influencing the countries since the early stages of the transition and had an immense impact on the form and formation of a political system, political parties system and, naturally, economic system. We attempt to demonstrate this ensuing fact by an analysis of the transformation process in Slovak society. Research on Europeanisation was mainly orientated on adapting institutions and the constitutional and legal framework to the rules and procedures resulting from the changing European environment. It is focused on the changes in domestic political institutions, processes and specific policies of the European countries in relation to the requirements of the EC / EU. In the 
last two decades of research and generalisation of experience gained by the countries of Central and Eastern Europe, many valuable results have been achieved, particularly in the study of the impact of Europeanisation on the political system of individual countries. The term of Europeanisation is closely related to the European integration processes and to the way how this complex process affects different spheres of policy in the countries associated with it, or how far it affects the framing of the new European political structure. These processes can overlap to a certain degree and affect policy at all levels. Perceived in this way, research had been neglected for a long time, and the study on national political systems was conducted separately from the research on the European integration (Fiala et al., 2009, p. 20). This fact was emphasised in the work of S. Hix and K.H. Goetz who wrote: "For a long time, the importance of the European integration in the development of indigenous political systems appeared to be empirically negligible and therefore it was not categorised as a monitored element of research. At present, a significant scope of research has been revealed in which the change and continuity of domestic (national) political systems would become a determinant depending on the form, direction and speed of the European integration process." (Hix, Goetz, 2000, p. 2). The European integration consists of two mutually connected processes: On the one hand, member states delegate political competences to the supranational level in order to obtain specific political results; on the other hand, a new structure of political institutions - including the executive, the legislative and the judicial - at the European level is established. Delegating powers affects policy outcomes at the domestic level as well. These effects are visible, for example, in public administration where the European integration can lead to the introduction of a new style of work. They can be seen also in the relationship between the executive and the legislative by the adoption of European legislation, and on creating new links between parties and voters or groups of voters which could affect individual parties as well as party systems.

„For a long time, the importance of the European integration seemed to be empirically uninteresting and therefore it did not belong to researchable issues. Only today, there is a broad space for the research in which a change and continuity of national political systems determined by the type, direction and speed of the European integration process becomes an important factor" (ibid.: 2000, s. 2 ). Europeanisation of policy can trigger a domestic change at three levels: a) institutional adaptation, b) change in the structure of domestic opportunities (due to a new distribution of power and resources between domestic actors), c) change of the framework of expectations in domestic policy. For this reason, the policies of the European Union can directly dictate a change in an institutional framework; they can also modify the institutional context of strategic interactions; or they can seek to the change of institutional 
framework indirectly by influencing the beliefs and expectations of domestic actors, who align their strategy accordingly (Knill, Lehmkuhl, 2002, pp. 255263). The processes of Europeanisation can be controlled by the European Union or by domestic actors and can be induced by dual logic: the logic of appropriateness (actors are motivated by internalised identities, values and norms) or the logic of consequences (maximizing the power of actors acting rationally). Europeanisation can arise only under the influence of external stimuli, i.e. conditionality corresponding to the dynamics initiated and controlled by the EU level. The European Union can set conditions as well as rewards or penalties for domestic actors based on their adaptability. The second approach is represented by a model of social learning stemming from the logic of appropriateness. It is based on domestic elites identifying with the EU requirements and adopting the rules by their own will and according to the belief that they are legitimate and represent the most appropriate solutions to domestic problems (Schimmelfennig, Sedelmaier, 2005, p. 8). Europeanisation conceived in this way is basically only one alternative of the transformation of political regimes in Central and Eastern Europe, i.e. a model of the so-called external transformation. Internal transformation is a process aiming at building functional and consolidated democracy and market economy and, therefore, it is generated by internal motivation of society willing to implement the necessary reforms. This factor might not be a necessary condition of external transformation. During the accession negotiations with applying countries, internal transformation was gradually replaced with external transformation, i.e. with transformation required from outside the country with the aim of accommodating political, economic and legal environments of the candidate countries to the EU requirements. V. Hloušek and M. Pitrová claim that this transformation is not followed by a broad public discussion and is seen as a "technical" rather than political problem. (Fiala, 2005, pp. 103-104). This argument can be only partially accepted, as after the accession to the European Union, seeking compromises among domestic elites is necessary. Several authors consider the democratic transition of countries in Central Europe and Europeanisation to be processes marked by many analogous features, and sometimes the transition is directly or indirectly equated to this democratic consolidation. V.Hloušek does not agree with applying the concept of Europeanisation to the phase of transition. According to him, it represents imitating Western European patterns in shaping a democratic political system, but it is not an immediate response to the stimuli related to the development of the EC/EU (Hloušek, 2004, pp. 101-102). Therefore, he assumes that at the stage of transition we cannot talk about the processes of Europeanisation or conditionality as these start after the transformation into the phase of consolidation. I do not think defining such strict borders is adequate since these 
processes interrelate and as the experience in Slovakia indicates, Europeanisation occurred already during the period of transition. Based on the transitological paradigm, defining the stage of completing the transition and the shift to the stage of democracy consolidation is quite a difficult task. Frequently, the EU membership or proximity to the EU membership is provided as a criterion.

The EU influence on forming the democratic institutions in Slovakia can be divided into three stages. The first stage concerned fulfilling the political demands representing the elementary precondition to obtain an invitation to the opening accession negotiations to the European Union. The second stage covered the period of the accession process after signing the Treaty of Accession between the European Union and the Slovak Republic and it reflected approximating to the laws of the European Union. The third stage began after Slovakia had joined the European Union and become a full member participating in shaping the policies of the European Union. Relations during the first two stages are asymmetrical, dominated by a direct vertical impact of Europeanisation and conditionality (top-down). In the third stage, the process is bilateral, marked by mutual influencing (both top-down and bottom-up).

Europeanisation could be responsible for creating a cleavage in EU member states, dividing the parties into pro-European and anti-European. However, such cases are quite rare. As a rule, the concept of the attitude towards the European Union is, to a greater or lesser extent, reflected in the programme lines and policies of most relevant political parties. Nevertheless, this does not diminish the importance of investigating the impact of Europeanisation on political parties. It is important to examine the indirect impact of Europeanisation on individual political parties - on their programmes, structure and practical policies. Simultaneously, two processes affect the functioning of political parties in European countries, both caused due to the process of European integration. "Firstly, the environment of national (domestic) political systems, which parties primarily exist in, is transformed; secondly, styles of policy making are modified" (Fiala, Hloušek, Suchý, 2008, p. 49). Therefore, demands required from political parties about promoting their political intentions were increased. The basic framework for studying the impact of Europeanisation on political parties was proposed by R. Ladrech who allocated five areas of examining the effect of Europeanisation on political parties. They are related to the changes in the political programme, organisational changes, the formula of party competition, the relations between the parties and government, the relations beyond the national party system (a new perspective of transnational cooperation between political parties) (Ladrech, 2002, pp. 396400): 
1. Changes in political programmes

In this area we will examine how attitudes and approaches to the European Union are reflected in the programmes of political parties, what attitudes they take to the deepening of integration; and the extent to which they install the internal agenda with regard to the needs of the European Union. There was a qualitative change in the approach to the EU as a factor of the solution politics, which was previously considered the domain of internal policy. In the last period, it was especially an important access of political parties to the instrument to overcome the debt crisis (EFSF, ESM) and measures aimed at the way out of the financial and economic crisis (Stability and Growth Pact, financial compact, European Semester, creation of the ECB banking supervision and banking union). We start from the fact that in the EU member states, Europeanisation can create its own line of cleavage, which would divide parties in pro-European and anti-European, but such cases are quite rare. As a rule, the concept of the attitude towards the EU is reflected in a greater or lesser extent, the programme lines and most of the relevant policies of the political parties. However, this does not diminish the importance of examining the effect of Europeanisation on political parties. It is important to examine the indirect effect of Europeanisation on political parties - on their programmes, structures, and their individual practical policy. This places bigger demands on the political parties to promote their political intentions.

\section{Organisational changes}

Political parties shall be governed by the structure of their bodies, creating a section or department for the area of the European Union, which are developing the issue into internal policies, as well as the attitudes and policies of the parties in relation to the EU and its policies. In addition, the parties shall develop mechanisms for the consolidation of the positions of its members, who have become members of the European Parliament, to work with these members.

3. Patterns of party competition

Political parties are obliged to include more or less issues of the EU in domestic discourse, which may influence the decision of voters. The theme of the European Union can become a dividing line to influence partisan rivalry and may even give rise to a conflict dividing line. The presence of the parties, profiling as pro-integration on the one side, and as Eurosceptical on the other one, may change the patterns of partisan competition and party system as well.

4. Party-government relations

Participation of the officials in the deliberations in the European Council or the Council of the EU may affect their relationships to their political party, and in 
some cases even split their attitudes, they can move away from the positions of the political programmes of the parties. It can change relations between the parties and government officials. The government can be forced by its political party to maximalist or minimalist attitude in relation to the further integration of the EU.

5. Relations beyond the national party system

Europeanisation may results in trans-national cooperation of political parties in each of the member states. The political parties are grouped based on partisan families, create a party faction in the European Parliament. Cooperation may result in a greater degree of integration, as in the plane of convergence programme outcomes and strategies until the institutional plane.

We can observe that Europeanisation has manifested itself in the aforementioned areas, at all stages of development of the political system of Slovakia, but with varying degrees of intensity and in various forms and guises. In the next explication, we will explore the effects of Europeanisation in all fields of activity of political parties and the party system in Slovakia.

The impact of the Europeanisation on political parties prior to the entry of Slovakia into the European Union

The idea of European integration, the Slovak Republic's orientation toward accessing the European Union, played a key role immediately after the totalitarian regime had been toppled and in all processes of democratisation, plural political system formation and economy transition. It can be said that the process of Europeanisation joined the process of transition. Due to this, all relevant political subjects established in Slovakia after 1989 had a task to form their opinion on the issue of European integration and to implement it into their programmes and internal political processes, and in this way they wanted to address the citizens who could potentially vote them. It is necessary to appreciate the fact that the European Union was open to the transforming postcommunist countries. The countries offered important prospects of their development that seemed to be attractive as a model of prosperous, democratic and safe countries of Western Europe. The situation was reflected in the motto of "Return to Europe" and it symbolised the affiliation and accepting the most important values valid in Western Europe, such as democracy, legal state, guaranteed human rights and freedoms, prosperity, and solidarity. At the same time, the conditions for a close and mutually advantageous economic and political cooperation with the EU countries were created. The perspective of the EU accession as of a union of prosperous countries was quite fresh and helped foster a fast economic development, overcome drawbacks and improve the process of approximation to the countries in Western Europe. Without the 
perspective and real overall assistance, the process of economic and political transformation and transition would be more complicated and uncertain. All political parties that were formed at that time, with some exceptions, claimed in their programmes their intention to access the European Union and NATO. It is necessary to emphasise that every party created the above-mentioned perspective based on its own opinion on the Union accession and on the position of Slovakia in the EU. As political parties and their political elite represented the chief decisive power in the process of society transformation, the relations and a real cooperation with other European political parties also played a key role in this process. The national political subjects joined the group of the existing European political parties what resulted in re-assessing the potential of their values, norms, standards, principles, and political programmes of their own. This variety of standardised methods and tools could be utilised by national political subjects while working on internal political and international projects. At the same time, when a political subject was permitted to join a union of European political parties, its credibility was improved as its policy was accepted by the union of political parties as a legal member proving that certain values, norms, standards and ideas are respected by the party. Due to this, all relevant Slovak political parties attempted to access any European political parties from their establishment. As political parties met the conditions for the accession, their international credibility was improved and the party was considered to be successful. This was a way how to help the national political parties grow mature and improve their profiles, and this factor could not be neglected in the process of transition. Then the success or failure of the party or its elite was in the hands of its politicians and representatives. The parties could make use of this chance to take a good position in the political parties ranking.

\section{The first European cleavage of Slovak political parties}

After the establishment of the independent Slovak Republic, in the early election in September 1994, the Movement for a Democratic Slovakia (HZDS) won with 35 per cent of the votes, and created a government coalition with the Slovak National Party (SNS) and the Association of the Workers of Slovakia (ZRS). The coalition had 83 seats in the National Council of the Slovak Republic (NR SR) that enabled it to obtain an absolute majority.

This coalition was created as a non-homogenous conglomerate of ideologically different orientations. It was not possible to achieve a consensus even in substantial questions of the governmental programme within interior and foreign policy. HZDS presented itself as a wide-spectrum movement of the centre but in fact it was its ambivalence which enabled calculations and by means of populist policy to cover a broad space from the left to the right centre and thus to keep the member base and a wide range of supporters. ZRS was an 
ambivalent radical left-wing subject with phenomena of extremism, which did not have any clear political programme. It often questioned privatisation despite its active participation in it, it did not agree with the basic foreign political orientation, with the entry to NATO and the European Communities (Lid'ák, Koganová, Leška 1999, pp. 109-114). After the establishment of independent Slovakia, the ethnic nationalism of SNS started to orientate itself towards the Hungarian minority, Roma population, but also to other ethnics and groups. Under the leadership of J. Slota, SNS was radicalised and it took a negative standpoint to everything non-Slovak, it often questioned the respected international organisations and institutions and disagreed with a substantial foreign political orientation. It was against the entry of the SR to NATO and proposed the principle of neutrality of Slovakia (ibid.: pp. 102109).

The Mečiar's government declared that it would continue the foreign political orientation of the former Czechoslovakia and publicly declared its interest in the entry to the Euro-Atlantic structures that people supported. On 4 October 1993, the Slovak Republic signed an association agreement with the EU about joining, which the National Council of the SR ratified on 15 December 1993.

In October and November 1995, the representatives of the EU sent to the Slovak government a diplomatic note that expressed worries about the development of democracy in Slovakia. The Union expressed its worry about the growth of intolerance of the government coalition to the opposition opinions and political decisions of the government regarding privatisation, violations of human rights and those of national minorities. These demarches and notes made a pressure of the international community on respecting the principles of parliamentary democracy and helped mobilise the opposition (Leška, 2011, pp. 73-74). However, Prime Minister Mečiar did not take them seriously and as evidence of sincere effort of the Slovak Republic to enter the EU, he submitted an application of the SR at the EU summit in Cannes on 27 June 1995. An important condition for becoming a member of the EU was fulfilling the so-called Copenhagen Criteria, which comprised requirements in political, economic and legal fields.

In its report about the progress of Slovakia, the European Commission expressed serious reproaches connected with the instability of the institutions and insufficiencies in democracy. Based on this evaluation, the European Council did not recommend to start accession negotiations with Slovakia in Luxembourg in December 1997. Thus, the Slovak Republic was excluded from the group of six candidate countries, and it fell out from the first round of enlargement of the EU. The relations between the EU and the SR were regulated by the individual Partnership for Entry that was focused on the 
Copenhagen criteria. According to them, Slovakia was not prepared, and it indicated a weaker position (Figel', Adamiš, 2003, pp. 10-11).

The politics of the coalition parties of HZDS, SNS and ZRS excluded Slovakia from the first group of the countries accessing the EU, and this was perceived by Slovak citizens as a failure of foreign policy which resulted in a drop of voter preferences. On the other hand, the opposition parties developed their election campaign based on the failure of the government coalition. They emphasised that they were able to manage the situation with the EU support. In this stage, there was also a visible cleavage of the political parties in their relations to the European Union.

Also in the 1990s, the Slovak political scene split into two blocs: "proMečiar" and "anti-Mečiar". The pro-Mečiar movement, the so-called "Mečiarism", overlapped more cleavages, especially in the direction of centre-periphery where nationalism played an important role, then in the direction of economic transformation as an antagonist radical reform vs gradualism, and the church vs state. It resulted in attracting supporters of an independent country of Slovakia (supporters of the nation and nationalists), supporters of gradualism, and those of privatisation in favour of national privatising entrepreneurs under the umbrella of an excuse of creating a "capital layer", and by most followers. The split of political parties represented a split of real pro-European parties and anti-European parties as well.

The issue of the European integration entered into the process of transition and became the main dividing line between the parties and determined the new formula of a competition of parties. It helped Slovakia to restore the trajectory of the democratic transition, the formation of parliamentary democracy.

$\mathrm{K}$. Henderson attributed the policy of rejecting the criticism of the European authorities by LS-HZDS in 1994-1998 to the "false Eurooptimism" that was a Slovak variant of Euroscepticism. (Henderson, 2005) On the contrary, all opposition parties presented their policy as pro-European, being able to overcome the deficit of democracy and ensure the Slovak access to the EU. Prior to the election held in 1998, the opposition based its reasons on the fact that it was able to manage Slovakia in the accession process. The fact played a key role in mobilizing Slovak voters. Most citizens - up to 54 per cent of the population - expressed their worries that Slovakia would not belong to the first group of the countries of the EU accession (Bútorová, 1998, p. 168).

The European conditions played a key role in the 1998 election when the coalition of LS-HZDS, SNS, and ZRS was defeated and democratic political parties won. This election result enabled to stop the process of building up an authoritarian regime of V. Mečiar's personal power and enabled the country to return to the process of developing parliamentary democracy and to overcome its political isolation. An important factor was also the support by the European 
political parties to the Slovak opposition parties, and their support by the institutions of the European Union, which gave promise that these parties would soon succeed. A number of representatives of the European Union said that the government, in which HZDS would be represented again, would not be credible and acceptable to the Union.

The political scene was divided into two blocs: nationalisticallyauthoritarian (HZDS, SNS, and later ZRS) and liberal-democratic (SDK, KDH, SMK, SDL') which composed a "quasi double-bloc" party system (Leška, 2013, p. 78). After the defeat of nationalistically-authoritarian bloc in the 1998 election, the formula of partisan competition changed. The coalition joined a wide range of rightist and leftist parties, which had in this stage a common goal - to restore parliamentary democracy and ensure the entry of Slovakia to the European Union. The party system of the "quasi double-bloc" model began to change to the model of moderate pluralism.

The new coalition government was created by the following liberaldemocratic political parties: the Slovak Democratic Coalition (SDK), the Christian Democratic Movement $(\mathrm{KDH})$, the Hungarian Coalition Party (SMK), the Party of the Democratic Left (SDL), and the Party of Civil Understanding (SOP), with Prime Minister M. Dzurinda at the head. The government coalition of Prime Minister M. Dzurinda had to remove the distortions of the former government in legislation, politics, and economy in a short time, and began to fulfil the Copenhagen criteria consistently. It established close contacts with the EU institutions to support activities of joint bodies of the EU, whose activity was aimed at accelerating implementation of the association agreements. Because of these efforts, the European Commission decided to open negotiations with Slovakia together with the Helsinki group.

Following the decision of the European Council in Helsinki in December 1999, the Slovak Republic, along with the other five candidate countries (Lithuania, Latvia, Malta, Bulgaria, and Romania), opened the entry negotiations in the opening meeting of the Accession Conference in February 2000. Slovakia undertook to implement legislation of the EU and to create the corresponding administrative capacity by the end of 2002. The reference date for the adoption and implementation of the "aquis communautaire" was set on 1 January 2004 (Figel', Adamiš, 2003, p. 16).

The European agenda played an important role in the 2002 election as well. After the elections in September 2002, the right-wing coalition consisting of the previous coalition parties of the Slovak Democratic and Christian Union 
$(\mathrm{SDKU})^{2}$, the Christian-Democratic Movement (KDH), and the Party of Hungary Coalition (SMK) came into existence. In order to ensure a parliamentary majority, a new political party of the Alliance of the New Citizen (ANO) had to be taken in the coalition. The new party coalition managed to overcome the delay in carrying out the accession negotiations in the implementation of Community law and, ultimately, the entry Slovakia into the EU. In this stage, real cleavages, particularly between the right and the left, and conservative and liberal approaches of the political parties got to the fore.

\section{The second European cleavage of Slovak political parties}

The second line of cleavage was revealed after the elections to the National Council of the SR in 2010. The Smer-SD party gained the largest number of votes; however, it failed to create a coalition government and, therefore, I. Radičová, leader of the SDKÚ-DS, had been appointed to rebuild the coalition. Considering the disappearance and weakening of the more established political parties and the emergence of new rightist parties (the Freedom and Solidarity ( $\mathrm{SaS}$ ) and Most-Híd), she managed to create a broad coalition of rightist parties (SDKÚ-DS, KDH, SaS, Most-Híd), which won 79 seats in parliament. I. Radičová became prime minister of the coalition government.

However, significant tensions between its liberal and conservative wings soon surfaced in the coalition, but mainly there was a contradiction in terms between the neoliberalism represented by $\mathrm{SaS}$ and the other parties of the government coalition. A critical situation occurred when the government submitted draft laws on the financing of European Financial Stability Facility (EFSF) and the creation of the European Stability Mechanism (ESM) to the parliament. The SaS party disagreed with the creation of the bailout fund and with aid of heavily indebted countries. Despite the fact that Prime Minister I. Radičová teamed up with members of the government coalition and she joined to vote on laws with the vote of confidence in the government, $\mathrm{SaS}$ members of parliament and some lesser parties voted against the law. As a result, the parliament expressed no confidence in the government, the government had to step down, and early election was announced. It was the first case in modern history of Slovakia that a member of coalition voted against the proposal of its own coalition government and caused its fall.

$\mathrm{SaS}$ is a new party. It gained the preference votes initially as a party, which mainly made itself visible on social networks to reach out to the younger generation, trying to make use of populism. Not only it managed to enter

${ }^{2}$ The Slovak Democratic Coalition, consisting of five coalition parties of KDH, DS, SZS, DÚ, and SDSS transformed into a separate political party of the Slovak Democratic and Christian Union (SDKU). 
parliament, but it became part of the ruling coalition and the chairman of $\mathrm{SaS}$ was also elected as chairman of the parliament. The programme of the party has been based on the principles of neoliberalism; it has required to make the most of the market and as little as possible of the effect of the state, and privatization not only in economy but also in services (education, health, social security, etc.). The party would like to apply principles of the market economy to all spheres of social life, and from this position, it criticised the European Union. The EU considers it as a "socialist project", just for the sake of regulation and intervention in the market economy. It refuses the existence of the temporary fund as well as of the permanent fund (ESM) and any financial assistance for the countries of the Eurozone, which find themselves in a debt crisis.

However, from the view of the Europeanisation, it is important that on the right side of the political spectrum arose a new line of cleavage, expressing the attitude towards the European integration. In particular, attitude towards to the measures taken by the Union to the rescue of over-indebted Eurozone countries and measures to deepen the integration as a way out of the economic crisis. In addition to the traditional divisions of the conservative and liberal parties, a new line arose among the right wing parties, expressing the attitude towards European integration. A three-pole configuration emerged, when in addition to the classical scheme of the competitive right wing party that had split to the left and the right, and liberal and conservative, a new neo-liberal pole appeared. This situation also had an impact on the pattern of partisan competition and affected the model of party system. Multi-party moderate pluralism has changed from a moderate system to a multi-party one with a dominating party.

In view of the financial, economic and debt crisis in the Eurozone and in the whole European Union, which requires solidarity, concerted actions and further deepening of integration (fiscal union, Union Bank), the coalition potential of $\mathrm{SaS}$ is approaching zero. The Common People and Independent Personalities party (OLaNO), which entered parliament after the 2012 elections, holds a Eurosceptic position as well.

\section{Relations beyond the national party system}

Regular contacts between Slovak and European political parties played a key role in terms of cooperation from different points of view. The parties had their representatives in the bodies of the European political parties, participated in their assemblies and board meetings when EU issues and attitudes towards the accession countries were discussed. The parties had an opportunity to gain some experience and recommendations in terms of reforms and the most effective way of meeting the integration criteria. On the other hand, they had an opportunity to interpret and explain the situation in Slovakia and to win the 
support of European parties for their own political agenda. Mainly the factions or political clubs of the parties represented in the European Parliament could support or accelerate the pre-accession discussions that seemed to be very useful for Slovakia after 1998.

The adoption of a political party into the European political parties increased its prestige and credibility, as reflected by the fact that it is accepted by the Association as a full member, that such a political party respected and applied in practice the values, standards and ideals of its political party's family. Therefore, all relevant Slovak political bodies sought entry to some of the European political parties. The adoption into the family of European political parties, once the necessary conditions had been fulfilled, was presented as a success and increase of the international prestige of the political party. This indirectly assisted the process of maturation and shaping of political parties in Slovakia, which is also a very important factor. It was then just a matter of political parties and their elites how to realise this potential and where to find a place in the political spectrum.

The first contacts with the European political parties, the first attempts to join these parties and start an effective cooperation were made in the 1990s. The conservative and socialist parties were successful in this field. The KDH party with its leadership under J. Čarnogurský was the first party that became an observer in the European Democratic Union (EDU) in August 1990. When EDU merged with the European People's Party (EPP) in December 1996, KDH obtained the status of an observer in EPP. It did not request the status of an associate member for a long time, as it did not prove the federalist character of the Union promoted by EPP.

The party of Hungarian Christian Democratic Movement (MKDH) became the observer in the EDU in September 1993. It did not become a permanent member, since it was blocked by $\mathrm{KDH}$ for a long time due to the political dispute concerning the placement of statues of the saints Cyril and Methodius in Komarno - a town lying in southern Slovakia where a large Hungarian minority lives. In 1998, three political parties representing the Hungarian minority joined and formed SMK - the Party of Hungarian Coalition. SMK obtained the status of an observer in EPP in December 1999 and it gained the status of an associate member in June 2000.

SDK was created before the election to the National Council in 1998, when the original election coalition consisting of five political parties (KDH, DÚ, SDSS, SZS, and DS) was registered as a self-reliant political party, and thus a candidate in the election. After the election, several political parties especially $\mathrm{KDH}$ - demanded the restoration of the original activity. M. Dzurinda, the chairman of the SDK party who became prime minister of a new governing coalition, disagreed, and created a new political party of SDKU on 
the basis of SDK. When the Slovak Democratic and Christian UnionDemocratic Party (SDKU-DS) was founded, it obtained the status of an observer in June 2002 and it became an associate member in May 2003.

HZDS attempted to communicate with left-wing parties, and later with conservative parties. Finally, it succeeded with liberal parties in 2009. In 1996, A. M. Húska, a member of parliament and an ideologist in LS-HZDS, promoted an idea of joining the European liberals, and the liberal members of parliament separated from the members of LS-HZDS in the European Parliament. V. Mečiar explained the conflict with the European integration of the party and claimed that the party had to make a decision if it accessed the existing organizations, or it should create new ones. Although the party declared its conservative nature and orientation that was reflected in the name of the people's party (LS-HZDS), in 2008 it succeeded in becoming an observer in the liberal Party of European Democrats (PED) forming a part of the faction of the Alliance of Liberals and Democrats for Europe (ALDE). In addition, the congress of EDP held in Bilbao in June 2008 proved that it had remained in the position of an observer, which was reflected in an unclear programme orientation of the party.

The SDL party together with the Social-Democratic Party of Slovakia (SDSS) obtained the status of an observer in the European Socialist Party (PES) in 1995, and both parties became associate members in March1999. Since Smer became more and more popular and its preference was increasing, there was an option to integrate smaller left-wing parties with Smer. Before the election to the European Parliament in 2004, Smer had won support of its counterparts, left-wing parties active within the framework of the Party of European Socialists (PES).

The new party (SaS), which entered parliament in 2010, joined the party of European Liberals and Democrats (ELDR) at its Congress in Helsinki in October 2010. Nevertheless, the chairman of the party, who had been elected into the European Parliament in the 2004 election, resigned from the faction of the Alliance of Liberals and Democrats (ALDE) and joined the faction of the European Conservatives and Reformists (ECR). The problem was that ALDE takes federalist approach to the European Union, which SaS strongly rejects.

After the elections in 2006, a part of the representatives of SMK with B. Bugár, the former party chairman, left the party and established a new MostHíd party (Bridge). Preferences of this party grew quickly and after the 2010 election it entered parliament, while the original SMK did not receive the necessary number of votes to enter parliament. The Most-Híd party applied for membership in the European People's Party in 2012. Its adoption was supported by KDH and SDKÚ-DS, but its entry was hindered by the competitive SMK. In spite of this, Most-Hid became a full member of EPP in November 2013. 
The Nova party became a member of European Conservatives and Reformists (ECR) in the meetings of the Committee on 31 October 2012. ECR brings together conservative parties from 18 European countries, for example, the British Conservative Party, the Czech Civic Democratic Party, and the Polish conservatives (PIS). The Slovak Civic Conservative Party (OKS) is a member of ACR as well.

\section{The Impact of the Europeanisation on the Development of the Slovak Leftist Parties}

R. Fico, member of parliament, left the parliamentary club of SDL and founded his own party of Smer in December 1999. The party soon became the most powerful left-wing party. It strongly criticised unpopular reforms made by the right-wing government coalition and gained more and more support in society. Smer had undergone various stages in its development, before it became mature. Firstly, the party presented itself as a no-ideology party of a new type that did not belong to the left wing. Keeping this position, the party criticised both the coalition and opposition, it called attention to corruption and breach of rights, and it accented pragmatic and new faces that appeared on the political stage. At that phase, the party could be assessed as a party of populism avoiding confrontation. Smer-SD forwarded itself to the position of a third way party, similar to the Labour Party rejecting its ranking as a socialist party (Marušiak, 2005).

At the last stage of the party development, Smer complemented its development as a social-democratic party supported strongly by the Party of European Socialists. Although there existed some antagonist declarations about the Smer orientation, in autumn 2002 its members of parliament, active as observers in the European Parliament, joined the group of the Party of European Socialists (PES) after they had discussed the situation with both the PES and SDL leadership and the Social-Democratic Alternative (SDA). The conditioned opportunity to cooperate with PES accelerated the process of the development of the party and had an impact on the results of the conference held on the programme of Smer in December 2002. The conference made a decision about the membership of the party in the Socialist International. The process was supported by PES that promoted a common attitude of centre-left parties, although the results before the election to the European Parliament in 2004 had not been positive.

There was another decisive moment in the process: an observer of the European Parliament for Slovakia was S.M. Wiersma, vice-president of the European Socialists, and at that time, he was in direct contact with the leadership of the party. SDL' as the strongest left-wing party was losing both its voters and influence after it was in the right-wing government coalition in 
1998-2002, as well as due to its vague programme and personal conflicts in the leadership of the party. Owing to its lessened power, the party did not enter parliament in 2002 and placed itself at the end of political activities, at the end of the national politics. Except for this, also the Social-Democratic Party of Slovakia and the Social-Democratic Alternative (SDA) separated themselves from SDL, and other left-wing parties ended up on the periphery of political life.

Therefore, the party's candidate list included names of representatives of the marginal non-parliamentary parties such as SDL, SDSS, SDA and SZS. The process was completed by the end of 2004, when SDL, SDSS and SDA fused with Smer. Based on this fusion, Smer incorporated the words "social democracy" into its name (Smer-SD) and became a member of PES in May 2005. The process of Smer-SD integration in the international organisations was completed in a formal way in May 2005, when it became a full member of PES.

\section{Changes in political programmes of Slovak political parties}

In Slovakia, there was neither a Eurosceptic, nor any anti-EU active political party up to the 2010 election. The political party of SNS acted as the most Eurosceptic party, but it adapted its programme with the coalition it joined. The coalition of SNS, HZDS and ZRS differed from the one with the party of SmerSD, when SNS supported the pro-European politics of R. Fico's party and approved the Lisbon Treaty in the National Council of the Slovak Republic. When this coalition was established, the party started to declare its more critical attitudes.

The SNS criticism towards the EU originated in the nationalist opinion of the SNS that national individualities were to be protected and not be lost in the EU. Due to the results of the 2009 election, SNS had its deputy in the European Parliament, so it joined a faction of the European Freedom and Democracy (EFD). It had been founded by merging of the parties forming factions of the Union for the Europe of the Nations (UEN) and the Independence and Democracy (ID) in the previous legislative period. Some parties in the EFD are considered ultra-right-wing and nationalist parties, especially UKIP (United Kingdom Independent Party) with its programme aimed at withdrawal of the United Kingdom from the EU. EFD officially intends to fight against the EU bureaucracy, it opposes integration deepening, and according to its opinion, all European treaties should be approved by a referendum. According to Farage, the merger should represent "a real alternative in the European Parliament".

$\mathrm{KDH}$ defended its careful opinion towards the integration deepening. Although it is a member of EPP, its opinion about the EU is based on a unity and cooperation of strong sovereign states. This was the reason why KDH 
opposed all the steps aimed at integration deepening. It had been against the approval of the Lisbon Treaty and before it was approved, the party had suggested passing the law on cultural and ethnic autonomy of Slovakia. Both the attitude and opinion of the party are based on the intention to preserve Christian norms and traditions of Slovakia.

The SDK party was created just before the election in 1998. Orientation for preparing conditions for the entry of Slovakia into the EU belonged to its programme priorities. The party publicly declared that, unlike the previous government, it would be able to bring Slovakia into the European Union, which gained it a lot of confidence and support of the voters. As the strongest party of the government coalition, it managed to fulfil the Copenhagen criteria, to establish negotiations with institutions of the EU, and to open accession negotiations with the EU. In addition, it managed to incorporate the community law in a short time, and as a result, Slovakia met all the conditions for entry in the EU. During the second term in office, a new Slovak Democratic and Christian Union - Democratic Party (SDKU-DS) was established based on SDK and presented itself as a liberal-conservative party. As a result, its policy in relation to the EU partially changed. It began to put more emphasis on the need to maintain economic autonomy (in fiscal and budgetary areas), and it disagreed with the transfer of some of the economic competencies to the EU authorities. After the outbreak of the economic and debt crisis in the Eurozone, it was as part of the government coalition against granting a loan to Greece, initially refused to create the EFSF and the ESM, although later it partially eased its position.

The strongest leftist party was the Democratic Party of the Left (SDL), which originated from the Communist Party of Slovakia (KSS) and adopted a social democratic programme. It was a Euro-optimistic party and in its programme it clearly supported the entry of Slovakia into the European Union. The party promoted this position also in practical policy, in the National Council, as well as in the government. The party was a member of the government coalition, which managed to win in the general election of 1998, and as a member of the ruling coalition it supported all measures aimed at the entry of Slovakia into the EU. After participating in the right-wing coalition and certain personal disagreements, preferences of SDL drastically decreased in the next election and it did not enter parliament. The Smer party that had merged with SDL' and other smaller political parties (SDSS, SDA) became the strongest leftist party.

When Smer acted as an opposition party in 1998-2002 and 2002-2006, it supported the orientation to the entry of Slovakia into the EU. From its position, it often criticised the government, especially SDKÚ, for its inability to negotiate appropriate conditions for Slovakia, and the country was not 
sufficiently prepared for its accession to the Union. Because of this position, some authors called Smer a Euro-pessimistic party, what was not correct.

In its programme and practical policy, Smer-SD acted as a Euro-optimistic party. When it was a government party in 2006-2010, it tried to prepare Slovakia for joining the Schengen area, and the country fulfilled the strict conditions for joining the monetary union and for adoption of the common currency, the euro. During its second government, the party won an absolute majority of votes in the 2012 elections and it was actively involved in taking measures to deepen the integration. Slovakia was actively engaged in the implementation of the Stability and Growth Pact as well as in meeting the financial criteria of the European semester. Slovakia met the requirements of the Pact and left the excessive deficit regime in 2014. It was involved in the formation of the banking union as well.

After the 2010 election, SaS won seats in the National Parliament. The party represents businessmen and entrepreneurs and its programme is based on neoliberalism. The party's opinions are Eurosceptic, and from this point of view, its criticism concerns regulation of some spheres of cooperation, applying for European funds, etc.

\section{The European Parliament election}

It was the first election held in 2004, shortly after Slovakia had accessed the EU. That means that Slovak political parties did not have much time to get ready for elections of such a type and they did not have much experience in this area. The election was carried out pursuant to the proportional representation with a closing clause of five per cent. The campaign had been considered very dull and not impressive, and it had not managed to address the citizens and mobilise the voter support.

SDKÚ and KDH had three MEPs, SMK had two of them, and KDH obtained 16 per cent of votes (such a result had never been obtained in the national election). The governing parties obtained totally 46.6 per cent of the valid votes and 8 MEP mandates. As for the opposition parties, both Smer-SD and L'S-HZDS were successful and obtained three MEP seats, and the opposition obtained 33,9 per cent of the valid votes. All three successful coalition parties were members of the European People's Party - European Democracy (EPP-ED), and they became members of their political factions in European Parliament. The deputies of Smer-SD became members of the Party of European Socialists (PES). As LS-HZDS had not been successful in joining any of the European political parties, its three deputies did not belong to any party.

Another important point was the preparation of the European Parliament election in 2009. Relevant parliamentary political parties had already 
cooperated with European parties, election programmes were prepared in a close cooperation with European political and national parties. The election programme of the strongest EPP faction was prepared by working groups consisting of representatives of political parties of the EU member countries, including the Slovak ones.

Based on the documents prepared by the groups, a common concept was developed by the central EPP committee (EPP: Ten Priorities for the EPP Group). In the preparation phase, the concept of the programme had been commented on and discussed with EU member countries, and finally it was approved by the EPP congress. The PES election programme had been worked out first in the PES centre in cooperation with the faction of socialists in the European Parliament, and afterwards it was submitted to the member parties to be discussed and commented on (PES: People First, A New Direction for Europe).

The programme was coordinated horizontally by the EU countries within the EPP structure and by the European Parliament. It can be said that both the European and Slovak political parties put a lot of effort in linking European and national areas of the current social problems and issues. Therefore, the programmes of Slovak political parties were aimed at the common European concept and from this point of view they developed a future concept of Slovakia.

The programmes of the SDKÚ-DS and Smer-SD parties were studied and the results showed that more than seventy per cent of the programmes issues were identical with the programmes of the European parties. In terms of forms and content, the election campaign was more interesting and challenging and it was dominated by the link between national and European issues. (Billboards, leaflets, TV campaign, radio and press campaign.) As the EU countries were concerned with the financial and economic crisis, a key moment in the preelection campaign was the possible results of the crisis. The attitudes of the right-wing and left-wing parties differed from each other and were easy to understand. PES pointed out that the crisis had been caused by an uncontrolled financial capital and free market, and therefore it insisted on promoting, supporting and developing a welfare state. On the other hand, EPP as a conservative party criticised the socialists that they were destroying positions and jobs, and made the position of Europe weak in the world.

Based on the Treaty of Nice that had come into force, the number of members of the European Parliament changed to 751, and the number of Slovak MEPs decreased from 14 to 13. From the point of view of political parties, the Smer-SD party obtained the largest number of votes -30 per cent, and due to this number, the party obtained 5 mandates. SDKÚ-DS with 16.98 per cent obtained two seats, and KDH with 10.87 per cent and SMK with 11.33 
per cent won two seats in the parliament each. Altogether, the right-wing parties united in the EPP obtained 6 mandates (The Results of the EP Election in 2009). The MEPs of the Smer-SD party had become members of the socialist faction with a new name, The Progressive Alliance of Socialists and Democrats (S\&D), because of a merger of the Party of European Socialists (PES) and the Italian Democratic Party, before its members-deputies were divided between PES and ALDE. The fact that a member of the parliament a member of Smer-SD became vice-president of the Socialist's faction in EP can be considered a success. In addition, one seat was won by LS-HZDS and that was a great drop compared to the previous election results when the party had obtained 3 members that proved a gradual decline of the party. Although the party was able to find its position in the European Political Party of Liberals.

One seat was obtained by the Slovak National Party that became a member of a new faction created after the election to the European Parliament - it was the Europe of Freedom and Democracy (EFD) founded by British nationalist N. Farage. The party replaced the group of Independence/Democracy. SNS officially declared that the party "became a member of a new Euro-realistic group with other important political subjects besides SNS" in the European Parliament. In fact, it was distant from Euro-realism, and many parties in EFD are considered by the national and European media extremely right-wing, antiimmigration-based, xenophobic, and racist. In this case, the membership of SNS in EFD can make a negative impression on its national policy and on its attitude to the European integration.

Another re-organisation in the European Parliament was conditioned by the fact that the Polish party of Right and Justice (PiS) abandoned UEN and along with the British conservatives and the Czech party of ODS founded its own group of the European conservatives and reformists (EKF). The faction has a Eurosceptic orientation.

The last election to the European Parliament on 24 May 2014 brought several surprises in Slovakia. One of them was that 29 political parties (in the framework of the two coalitions) took part in the election, although in the previous general election it was only 18 parties, and the second surprise was the historically lowest turnout of voters -13.05 per cent. These two factors affected the results of the election held in the shadow of the economic and debt crisis. Although in the revival of economy, employment in the European Union has grown very slowly. The unemployment rate is high in the EU, especially in the heavily indebted countries in the Eurozone where unemployment of young people reaches up to 50 per cent. The economic and debt crisis, which began in 2009, and the measures taken by institutions of the Eurozone and the EU were a good breeding ground for the growth of Euroscepticism, nationalism, racism, 
xenophobia, and anti-European sentiments. Questioning of and suspicion against the EU during this period naturally appeared also in Slovakia. The strongest and most aggressive Eurosceptic campaign was that carried out by the $\mathrm{SaS}$ party, which steadily kept raising the issue of the EU. In its electoral programme, the slogan "All for Brussels, we for you!" expressed its idea of the Union. The party questioned the EFSF and ESM activities, measures adopted by the Union and expressed ideas, which, however, were out of reality.

A low turnout of voters was reflected mainly in the negative results of the strongest party of Smer-SD, which won three seats, i.e. one seat less than in the previous term of office. KDH and SDKÚ-DS received two mandates, which is compared to their internal political position a success, and Most-Híd and SMK received one mandate each, though SMK have no representation in the national parliament.

The parties of KDH, SDKÚ-DS, Most-Híd, and SMK was based their campaign on principles of the European People's Party. At the same time, they emphasised their own ideological principles. They want to achieve an economic revival by structural changes, creation a new jobs, simplifying the administration, and capital attracting. All these parties believe these standard measures could strengthen the budgetary discipline and help create the Banking Union.

The Smer-SD party, which is a member of the Party of European Socialists (PES), promoted guarantees for young people and an increase in the budget for this purpose. It supported a regulation of the financial sector, stressed the strong role of the EU in the economic and industrial policy, including economic growth, strengthening the importance of agriculture and food in the Slovak economy, promoting the European system of minimum wages and stressing the need for a common budget for the Eurozone.

The low turnout in Slovakia, which was the lowest in the EU, resulted probably from the spread Euroscepticism or fatigue from elections, because there were regional self-government and presidential elections in that year. The discrepancy between the highest confidence in the EU institutions and the lowest participation in the elections apparently stemmed from the fact that citizens were aware of the benefits connected with being in the EU, but they felt that our members of the European parliament could not affect activities of the EU.

\section{Conclusion}

Our research proved that Europeanisation had manifested itself in all stages of the development since the signing of the association agreement with the European Union, but with varying degrees of intensity and in various forms. 
In the 1990s and after the elections to the National Council in 2010 and 2012, a separate cleavage of the Europeanisation of political parties was created and it possibly became their important part. The creation of a separate competition, the possibility of creating a partisan coalition formula would affect the cleavage and hence the overall model of the political system. After the elections in 1998, there was a breakup of the double-bloc scheme of partisan competition, where one bloc comprised nationalistically-authoritarian parties (HZDS, SNS, and ZRS) and another block comprised liberaldemocratic parties (KDH, SMK, DS, DÚ, SDL, and SDSS). The party system began its transition from the "quasi double-bloc" system to a modest plurality system.

The fall of the right-wing coalition government in 2012 was caused by the attitude of the SaS party to rescue heavily indebted countries and to the measures of the EU to find a way out of the crisis. The disintegration of the coalition caused a significant decrease in preferences of the rightist political parties and their failure in the early elections in 2012 . The election was won by the Smer-SD party with 83 seats in parliament, which enabled it to set up a one-party government. The multi-party pluralism has been changed from the moderate system to a multi-party system with a dominating party.

The impact of Europeanisation has been most pronounced in the programming documents of all political parties, which have been forced to take a stand on the pre-accession negotiations or on the process of European integration after the entry of Slovakia to the EU. In this respect, it was a very important factor regarding the entry of Slovak political parties to European political parties, which began after the signing of the Association Agreement. After the accession of Slovakia into the EU, their cooperation reached a qualitatively higher level opening new possibilities for cooperation and policy coordination. The impact on the programme orientation of political parties, as well as cooperation with the EPS was significant during the elections to the European Parliament in 2004, 2009, and 2014. The preparation of electoral programmes forced all relevant political parties to take a stand on the current issues of the European integration and to incorporate it into the domestic political processes.

There were also changes in the organisational structures of political parties, focused on the mechanism of nomination of candidates for the election to the European Parliament, institutionalisation of cooperation with their members of the European parliament, cooperation between the highest bodies of a party and the European political parties, whose members they were, as well as the mechanisms for cooperation and policy coordination.

The impact of Europeanisation on the relationship between a political party and the government emerged in part during the office of Prime Minister I. 
Radičová in the period of the economic and debt crisis in both the Eurozone and the EU. Her mother party of SDKU-DS adopted a reserved attitude towards the aid for the countries in debt. Prime Minister I. Radičová participated in several feverish negotiations of the European Council and she agreed with the opinion on necessity of the support for the indebted countries, and her position was promoted in the government and later in the National Council. She had no unambiguous support even in her own political party and she came into conflict with her own party and mainly with other members of the coalition government, which eventually resulted in the downfall of the government.

\section{BIBLIOGRAPHY}

ALDE: 10 political priorities. [online] 2009 [cit. 2009-11-08] Dostupné na: http://www.alde.eu/fileadmin/webdocs/key_docs/10Priorities-booklet-EN1.pdf

BARTOLINY, S.: A Comparative Political Approach to the EU Formation. In: Working Paper, Arena, [online] 2006, No. 04 [cit. 2010-07-13] Dostupné na: http://www.arena.uio.no

BARTOLINI, S. - MAIR, P.: Identity, competition, and electoral availabitity: The Stabilisation of European Electorates 1885 - 1985. Cambridge: Cambridge University Press, 1990.

BLONDEL, J.: Party Systems and Pattern of Government in Western Democracies. In: Canadian Journal of Political Science, Vol. 1, No. 2, 1968, pp. $183-203$.

BLONDEL, J.: Comparative Government. An Introduction. London: Prentice Hall, 1995.

BRUSIS, M.: European Union Enlargement and the Europeanisation of Eastern Europe: reaserch puzzles and policy issues. In: Mansfeldová, Z. - Sparschuh, V. - Wenniger, A. (Eds.): Patterns of Europeanisation in Central and Eastern Europe. Hamburg: Krämer, 2005, pp. $21-38$.

BÚTOROVÁ, Z.: Vývoj názorov verejnosti na vstup Slovenska na NATO. In: Bútora, M. - Šedej, F. (Eds.): Slovensko v šedej zóne? Rozširovanie NATO, zlyhania a perspektivy Slovenska. Bratislava: IVO, 1998, pp. $167-184$.

EPP: Ten priorities for the EPP Group 2009 - 2014. Putting people at the heart of Europe. [online] 2009 [cit. 2009-11-08] Dostupné na: http://stream.eppgroup.eu/Activities/docs/ year2009/2009-2014group-prioritiesen1.pdfv

FEATHERSTONE, K.: Introduction: In the Name of Europe. In: Feastherstone, K.- Radaelli, C., M. (Eds.) The Politics of Europeanisation. Oxford: Oxford University Press, 2003, pp. 3 - 27.

Evaluation of the European Parliament Elections 2004. [online] 2004 [cit. 200425-03] Dostupné na: 
http://europa.eu/legislation_summaries/justice_freedom_security/citizenship of the union/116024_en.htm

FIALA, P. a kol.: Evropeizace zájmů. Politické strany a zájmové skupiny v České republice. Brno: Munipress, 2009.

FIALA, P.- MAREŠ, M.- SOKOL, P.: Eurostrany. Politické strany na evropské úrovni. Brno: Barister \& Principal, 2007.

FIGEL, J. - ADAMIŠ, M.: Slovensko na ceste do Európskej únie - Kapitoly a súvislosti. Bratislava: Slovenská spoločnost' pre zahraničnú politiku, 2003.

GROTE, J.: Deliming Europeanisation. Paper for presentation at the Merburg Conference Session, ECPR, Marburg 18 - 21 September 2003[online] 2003. [cit. 2010-07-13] Dostupné na: http:///www.essex.ac.uk/ecpr.

HENDERSON, K.: Evropeizace politických stran na Slovensku. In: Fiala, P. a kol. Evropeizace zájmì. Politické strany a zájmové skupiny v České republice. Brno: MUNI Press, 2009, p. 297 - 310.

HENDERSON, K.: The Slovak Republic: Eurosceptics and Phoney Europhiles. In: Szczerbiak, A. - Taggart, P. (eds): The Party Politics of Euroscepticism. Oxford: Oxford University Press, 2005.

HENDERSON, K.: Europeanisation of Political Parties: Redefining Concepts in a United Europe. In: Sociológia, Vol. 41, No. 6, 2009, pp. 526 - 538.

HIX, S. - GOETZ, K. H.: Introduction: European integration and National Political Systems. In: West European Politics, Vol. 23, No. 4, 2000, pp. 1 - 26.

KNILL, Ch. - LEHMKUHL, D.: The national impact of Europan Union regulatory policy: Three Europeanisation mechanisms. In: European Journal of Political Research. Vol. 41, No. 2, 2002, pp. $255-280$.

KOPEČEK, L.: Slovensko. In: Strmiska, M.- Hloušek,V.- Kopeček, L.- Chytílek, R.: Politické strany moderní Evropy. Analýza stranícko-politických systému. Brno: Portál, 2005, pp. 453 - 479.

KOPEČEK, L. (ed): Od Mečiara k Dzurindovi. Slovenská politika a politický systém v prvním desetiletí samostatnosti. Brno: Masarykova univerzita v Brně, 2003.

KOPEČEK, L.: Demokracie, diktatury a politické stranictví na Slovensku. Brno: CDK, 2006.

KRNO, S.: Typológia politických strán (so zretelom na transformujúce sa štáty. Nitra: UKF, 2006.

KUBÍN, L'.: Rola politických elít pri zmene režimu na Slovensku. Bratislava: Veda, 2002.

KUBÍN, L.: Politické elity. In: Sopóci, J. a kol.: Slovensko v devätdesiatych rokoch. Osem pohladov. Bratislava: UK, 2003, pp. 7 - 83.

LADRECH, R.: Europeanisation and Political Parties: Towards a Framework Analysis. In: Party Politics, Vol. 8, No. 4, 2002, pp. 389 - 403.

LADRECH, R.: The Europeanisation and Political Parties. In: Bulmer, S. Lequesne, CH. (Eds.) Member States of the European Union. Oxford: OUP, 2005 , p. $317-337$. 
LEŠKA, D.: Europeanization in the Processes of Transformation of the Political system in Slovakia. Gdańsk: Harmonia Universalis, 2014.

LEŠKA, D.: Hlavné etapy formovania systému politických strán na Slovensku po roku 1989. In: Sociológia, Vol. 45, No. 1, 2013, pp. $71-88$.

LEŠKA, D.: Politický systém Slovenskej republiky. Bratislava: Univerzita Komenského, 2013.

LEŠKA, D.: Postavenie Slovenska v EÚ. In.: Goňcová, M. a kol.: Evropská integrace. Brno: Masarykova univerzita, 2012, pp. 114 - 166.

LEŠKA, D.: Vývoj politickej scény na Slovensku a Európske politické strany. In: Evropská politická společnost. Brno: Masarykova univerzita, 2010. pp. 179215.

LIĎÁK, J. - KOGANOVÁ, V. - LEŠKA, D.: Politické strany a hnutia na Slovensku po roku 1989. Bratislava: Ekonóm, 1999.

LINZ, J. - STEPAN, A.: Problems of Democratic Transition and Consolidation: Southern Europe, South South Afrika and Post-Communist Europe. Baltimore: John Hopkins University Press, 1996.

LIPSET, S., M. - ROKKAN, S.: Cleavage Structures, Party Systems and Voter Alignmensts: An Introduction. In: Lipset, S. M. - Rokkan, S. (Eds.): Party Systems and Voter Alignments. Cross national Perspectives. New York: The Free Press, 1967, pp. $1-64$.

Lisabonská zmluva. Konsolidované znenie Zmluvy o Európskej únii a zmluvy o fungovaní Európskej únie. [online] (2010/C 83/01) [cit. 2013-20-11] Dostupné na: http://eurlex.europa.eu/LexUriServ/LexUriServ.do?uri=OJ:C:2010:083:FULL:SK:PDF

MAIR, P.: The Limited Impact of Europe on National Party Systems. In: West European Politics, Vol. 23, No. 4, 2000, pp. $27-51$.

MAIR, P.: Political Parties and Party Systems. In: Graziano, P. - Vink, M. (Eds.) Europeanisation: New Research Agenda. Basingstoke: Palgrave Macmillan, 2005, pp. $154-166$.

MARUŠIAK, J.: Fenomén strany Smer: medzi „pragmatizmom“ a sociálnou demokraciou. In: Stredoevropské politické studie, Vol. XIII, No. 4, 2006. [online] 2006 [cit. 2008-20-07] Dostupné na internete: http://www.cepsr.com/clanek.php?ID $=258$

MARUŠIAK, J.: The Political System in the Slovak Republic. In: GIZICKI, W. (Ed.): Political Systems of Visegrad Group Countries. Trnava - Lublin: UCM Trnava, 2012, pp. $107-148$.

Občianska zodpovednost’ a spolupráca. Programové vyhlásenie vlády Slovenskej republiky na obdobie rokov 2010 - 2014. August 2010. [online] 2010 [cit. 2010-18-10] Dostupné na: http://www.government.gov.sk/data/files/6257.pdf

O'DONNELL, G. - SCHMITTER, P.: Transition from Authoritarian Rule. Tentative Conclusions about Uncertain Democracies. Baltimore: The John Hopkins University Press, 1986. 
PES: People first, A new direction for Europe [online] 2009 [cit. 2009-11-08] Dostupné na: http://www.pes.org/downloads/PES_manifesto_2009-EN.pdf (11.8.2009)

RADAELLI, C. M.: The Europeanisation of Pubic Policy. In: Featherstone, K. Radaelli, C. M. (Eds.): The Politics of Europeanisation. Oxford: Oxford University press, 2003 , pp. $27-57$.

SARTORI, G.: Strany stranické systémy. Schéma pro analýzu. Brno: CDK, 2005.

SCHIMMELFENNIG, F. - SEDELMEIER, U.: Introduction: Conteptualizing the Europeanisation of Central and Eastern Europe. In. Schimmelfennig, F. Sedelmeier, U. (Eds.): The Europeanisation of Central and Eastern Europe. Ithaca and London: Cornell University Press, 2005.

Ústava Slovenskej republiky s úvodným komentárom. Úplné znenie zákona, stav k 1. marcu 2009. Bratislava: Heuréka, 2009.

Výsledky volieb do Európskeho parlamentu 2009. [online] [cit. 2010-25-03] Dostupné na internete: http://ec.europa.eu/slovensko/news/vysledky_eurovolieb_2009_sk.htm

Výsledky volieb do Európskeho parlamentu 2014. [online] 2014 [cit. 2014-25-03] Dostupné na: http://www.eurovolby2014.sk/vysledky-volieb-do-europskehoparlamentu-2014-v-eu/

Dušan Leška is an associate professor in the area of theory of politics at the Department of politics and European studies, Faculty of Social Sciences of University ss. Cyril and Methodius in Trnava. His main research domains are the formation of the political system, stages of the development of party system in Slovakia and etc. The most important publications in this area include: Leška, D.: Formovanie politického systému na Slovensku po roku 1989. Bratislava: Infopress, 2011. [Formation of the Political System in Slovakia Ater 1989] ; Leška, D.: Politický systém Slovenskej republiky. Bratislava: UK, 2013. [Political System of the Slovak Republic]; Leška, D.: Hlavné etapy formovania systému politických strán na Slovensku po roku 1989. [The Main Stages of the Formation of Political Parties System in Slovakia After 1989]. In: Sociológia. Roč. 45, č. 1 (2013), s. 71-88. Other areas of his scientific research include questions of development of the European Union, European integration, Europeanisation of political and party system in Slovakia, economic and debt crisis in the EU and the Eurozone, the causes of the outbreak of the crisis and its consequences. The most important works from these areas are: Leška, D.: Europeanization in the Processes of Transformation of the Political System in Slovakia. Gdańsk: Harmonia Universalis, 2014; Leška, D.: Postavenie Slovenska v Európskej únii. In: 
Evropská integrace: od projektu k realizaci. Brno: Masarykova univerzita, 2012 [Position of Slovakia in European Union. In: European Integration: from Projects to the Implementation]; Leška, D.: The current economic and debt crisis in eurozone and crisis of grand theories of European integration. In: Human Affairs. Vol. 23, no. 3 (2013), s. 429-442.

Doc. PhDr. Dušan Leška, PhD. Katedra politológie a európskych štúdií Fakulta sociálnych vied Univerzita Cyrila a Metoda v Trnave Ul. Bučianska 4/A dusan.leska@ucm.sk 